\title{
A Moderation and Mediation Model of Social Media Marketing and Brand Loyalty Among Smartphone Users in Egypt
}

Omnia A. Hilal, Faculty of Commerce, Zagazig University, Egypt

(iD) https://orcid.org/0000-0001-6757-0428

\begin{abstract}
Social media are being extensively used as a platform to conduct marketing and advertising activities. However, there is always a challenge in how organizations can figure out the results of social media marketing. Therefore, this study aimed to study the effect of social media marketing on brand loyalty among smartphone users in Egypt and to identify the effect of some demographics and psychographics on this relationship. A cluster sample consisting of 502 smartphone users has been surveyed using a questionnaire that has been designed and validated. Ex-post facto design was employed to achieve the research objectives. Multi-group analysis and path analysis were employed to test research hypotheses. Results showed that social media marketing significantly affects brand loyalty, and smartphone users' age and education significantly affect this relationship. Finally, smartphone users' psychographics significantly affected this relationship.
\end{abstract}

\section{KEYWORDS}

Brand Loyalty, Demographics, Ex-Post Facto Design, Psychographics, Smartphones, Social Media Marketing

\section{INTRODUCTION}

Social networking is providing a whole new level of communication between marketers and consumers (Shareef et al, 2019). Indeed, 4.20 billion are on social media out of 4.66 billion on internet (Annual Digital Report, 2021), therefor, countless consumers and potential consumers can be reached through various digital channels: emails, social networking sites, blogs and micro-blogs, peer review or referral sites, and social content sites. Hence, more companies are encouraged to use social media as an important part of their online marketing strategies (Chen \& Lin, 2019) as more people are joining social network sites suggesting to conduct a new business platform in e-commerce, known as social commerce (Abdelsalam et al, 2020).

Many organizations use social media to promote their products, as well as simply share information (Golijan, 2011) as it is an ideal form of communication to reach a large audience as well as specific targeted audience that do not require any financial resources (Michaelidou et al, 2011). Social media bring an interesting dynamic to the sales and marketing interface at which customers want to voice 
their concerns and want to be educated on products and services as a move from passive to active presence, (Liu, 2012; Marshall et al., 2012).

Stephen, (2016) assured that most of consumer marketing in the future will be carried out in digital settings, particularly social media. With the increased use of social media marketing by several types of brands, it has become crucial to study and analyze this phenomenon. The value of social media data is rarely discovered, analyzed and visualized (Hajli \& Laroche, 2019). Thus, studying the consequences of social media marketing is the main purpose of this research targeting to spot more light on this new technological marketing communication strategy through investigating the effect of social media marketing on brand loyalty.

Smartphones have become an inseparable part of our daily lives. Nowadays, smartphones and social media go hand in hand as $92.6 \%$ of global browsing social media is through smartphones (Annual Digital Report, 2021). In recent years, mobile devices have taken social media marketing to a whole new level as users continually choose to access their networks remotely, via smartphones, tablets, and laptops. Therefore, studying the effect of social media marketing on brand loyalty among smartphone users in Egypt will enhance marketers' understanding and knowledge about consequences of social media marketing and factors affecting this relationship.

The scientific contribution can be presented through several points. Based on the challenge of how organizations can figure out the results of Social media marketing (Costa et al, 2018) especially in the light of the scientific gap represented in the contradiction between previous researches' results, this study is among the first to fill the gap through testing the consequences of social media marketing in terms of brand loyalty among smartphone users in Egypt. Moreover, in a trial to extent the theoretical contribution, the current study different from previous studies, investigated the role of demographics and psychographics in the relationship between social media marketing and brand loyalty among smartphone users in Egypt.

The causal research design has been used as it is the only research design that enables exploring the cause-effect relationships through executing experiment (Sekaran \& Bougie, 2016, El-Assi, 2019). Ex-post facto experimental design, different from previous studies, has been chosen to achieve the research objectives. It hasn't been studied in social media marketing context in Egyptian or foreign contexts which will support the causality of the relationships and enhance the scientific contribution of the current study.

\section{THEORETICAL BACKGROUND AND HYPOTHESES}

\section{Social Media Marketing and Brand Loyalty}

The old way of branding and marketing a product through one-way media such as newspapers, magazines, radio, television, and direct mail is now unconventional and outdated especially in the new age of information and new technologies, (Alkhas, 2011). Marketers are now are now required to compete with new marketing strategies which are based on interaction, information, education, and choice (Scott, 2007). The feedback from customers has also become vital for businesses because customers are not able to share opinions on the web where other customers can also see this feedback (Alkhas, 2011).

Social media users are active to share, interact and participate in producing online content (Ioakimidis, 2010). Social networks also provide opportunities to marketers including the ability to listen to fans, respond to them, discuss issues, reach common understandings, and in due course, strengthen long-term relationships (Williams \& Chinn, 2010). The more an organization or brand are trustworthy, or responsible, or insightful from publics point of view, the more they are perceived as credible. When publics are talking about these features, they create electric-word-of-mouth which is one of the strengths of social media marketing. 
Social media marketing has been defined as "a philosophy and a business strategy, supported by a technology platform, business rules, workflow, processes and social characteristics, designed to engage the customer in a collaborative conversation in order to provide mutually beneficial value in a trusted and transparent business environment" (Evans, 2010). This definition highlighted that social media marketing is different from traditional marketing where social media marketing provides several opportunities for marketers and customers. Marketers can now achieve user generated classification and engage in interactive communication with potential and current consumers. Customers from the other side can take control of information content, communication, or other related activities about a brand (Garnyte \& De Ávila Pérez, 2009).

Empirical research regarding the specific use of social network sites has described advertiser credibility (Lee et al, 2011); dimensions of uses and gratifications (Bonds-Raacke \& Raacke, 2010); user personalities and motivations for use (Ross et al., 2009); and, involvement (Muntinga et al, 2011), its effect on spreading investment culture in Egypt (Galal, 2017), and effectiveness (Calder et al, 2009).

Previous studies concerning social media marketing aimed at assessing its usage and effectiveness (Marzouk, 2016; Ouoba, 2011), strategies (Chanthinok et al, 2015; Karimi \& Naghibi, 2015; LorenzoRomero et al, 2013; Gordon, 2017), barriers and measurement (Michaelidou et al, 2011), public opinion formulation (Gazzar, 2013), considerations and implications (Botha, 2014), opportunities and challenges (Abeza, 2012), cultural, ethical and legal considerations (Amin et al, 2017), antecedents and consequences (Somali, 2018), and adoption models and stages (TsitsiChikandiwa et al, 2013). Another stream of studies focused on understanding how social media marketing impacts marketingrelated outcomes, such as consumers' purchase intentions (Wang et al, 2012; Hutter et al, 2013), brand perceptions (Naylor et al, 2012), the selling environment (Marshall et al., 2012), company ROI (Fisher, 2009; Hoffman \& Fodor, 2010), customer equity (Kim \& Ko, 2012), brand awareness (Hutter et al, 2013), and brand equity creation (Bruhn et al, 2012). Finally, social media marketing effect on business growth (Aloch, 2017) has been studied.

Although Social media marketing is considered a new rapidly growing platform for branding, its impact on number of psychological and behavioral consequences, especially in middle east context, is still missed. Brand loyalty is a brand aspect that has attracted scholars' and practitioners' attention in the last few years. Nevertheless, how Social media marketing can result in enhancing this aspect, in other words, social media marketing consequences in the terms of brand loyalty is yet to be understood.

Brand loyalty has attracted the attention of both academicians and practitioners over the past decade as one of the most important marketing concepts (Alhaddad, 2015). Market is full of substitute brands in certain product categories and consumers may perceive no differences among them when evaluating brands, but loyal customers are less price sensitive, resist competitors' efforts, spread positive word-of-mouth, and perceive high product or service quality. Therefore, brand loyalty is a key determinant of the value of brands (Aaker, 2012), and studying the factors affecting it is of mass importance (Schultz, Block, and Viswanathan, 2014).

Brand loyalty is defined as "a deeply held commitment to re-buy or re-patronize a preferred product/service consistently in the future, thereby causing repetitive same-brand or same brand set purchasing despite situational influences and marketing efforts having the potential to cause switching behavior" (Oliver, 1999). The relationship between social media marketing and brand loyalty has been researched over the past period of time; nevertheless, it isn't clear or specific. It has been proved that when the brand performs social media marketing through offering advantageous campaigns and offering relevant and popular contents on social media, brand loyalty is directly affected and enhanced (Gunelius, 2011; Chung \& Austria, 2010; Azadi \& Rahimzadeh, E., 2012; Swani et al, 2013; Erdoğmuş \& Cicek, 2012).

Despite the numerous papers that have proved that there is a positive relationship between social media marketing and brand loyalty, there are a sufficient number of papers that present a new perspective. Laroche, Habibi, \& Richard (2013) claimed that the relationship between social media marketing and brand loyalty is mediated by brand use and brand trust, while Zheng et al (2015) and 
Lim et al (2015) argued that the relationship is mediated by brand commitment. Finally, Tatar and Erdog mus (2016) concluded that the direct relationship between social media marketing is denied. This highlights a scientific gap represented in relationship ambiguity which requires more research and investigation and leads to the formulation of following hypothesis:

Hypothesis 1: Social media marketing significantly affects brand loyalty among smartphone users in Egypt.

\section{Social Media Marketing, Brand Loyalty, and Demographics}

It is clear from the literature review above that there is a scientific gap concerning the relationship between social media marketing and brand loyalty; some studies proved that social media marketing affects brand loyalty while other proved that there is an indirect effect. Studying the same issue repeatedly will have limited contribution to social media marketing knowledge. That pushed the researcher to think of a mediating or a moderating variable, its absence has led to this gap.

Demographics provide descriptive information about who product buyers are. Businesses owners need demographics to determine the target market for products or services and tailor suitable marketing strategies (product packaging, advertisements, business location and pricing) for it. Hustad $\&$ Pessemier (1971) suggested that the value of demographic information is primarily in identifying whether a consumer has a basic need for a product and whether he is capable of purchasing it.

Demographic characteristics provide a relatively straightforward and reliable basis for segmentation (Blackwell et al, 2006; Koufaris, 2002), moreover, it has been shown to play a significant role in determining the behavior of individuals and web users (Girard et al., 2003). Based on the previous argument, in the context of our study, some demographic variables (gender, age, and education) will be examined to determine if they affect the relationship between social media marketing and brand loyalty among smartphone users in Egypt. These demographic characteristics are most popular among researchers (e.g., Gironda, 2014; Leung, 2012; Kim \& Ko, 2012; Hassan, 2015 ) and they have a direct influence on consumers' lifestyle and behavior and represent individual consumer differences (Dayan et al, 2017). Therefore, the following hypotheses have been formulated:

Hypothesis 2: Consumers' gender significantly affects the relationship between Social media marketing and brand loyalty among smartphone users in Egypt.

Hypothesis 3: Consumers' age significantly affects the relationship between Social media marketing and brand loyalty among smartphone users in Egypt.

Hypothesis 4: Consumers' education significantly affects the relationship between Social media marketing and brand loyalty among smartphone users in Egypt.

\section{Social Media Marketing, Brand Loyalty, and Psychographics}

Demographic variables alone are generally not "powerful" predictors of individual or household behavior in the marketplace (Bieda \& Kassarjian, 1971). The limitation of studying demographics alone leaded to the development of psychographics. The new construct, psychographics -or commonly known as lifestyle-combines the benefits of demographics with the deeper dimensions of psychological characteristics.

Psychographics are factors that explains consumer behavior (Pieniak et al, 2008; Brunsø et al, 2009 by which consumer's decision-making process is affected. It consists of consumer aspects such as personality, buying motives, interests, attitudes, beliefs, and values.

According to Engel et al (1990) psychographics are used to develop an in-depth understanding of market segments and therefore used for developing marketing strategies for brands. The purpose of the analysis is to "understand consumer lifestyles of the core consumers in order to communicate more effectively with people in that segment. However, knowledge about the role psychographics 
play in Social media marketing usage is still missed. In addition, marketers can easily get consumers' demographic, geographic, psychographic information from their Facebook profiles and tailor marketing efforts to each group of consumers (Hoy \& Milne, 2010).

In conclusion, psychographics play an important role in consumer decision making process, can affect consumer perception of different marketing aspects, and examining psychographic constructs is extremely important in marketing research (Gironda, 2014), but how could they mediate the relationship between Social media marketing and its possible outcomes is yet uncovered. This argument leads to formation of the following hypothesis:

Hypothesis 5: Consumers' psychographics significantly affect the relationship between social media marketing and brand loyalty among smartphone users in Egypt.

Providing insight to this issue will help those making marketing decisions better understand the effects that having for example a Facebook brand page or a twitter brand platform might have on brand loyalty, and the role of some demographics and psychographics play in these relationships. Figure (1) shows the research proposed model and hypotheses.

As shown in the figure, demographics role will be tested through moderation analysis as they are not affected by the independent variable (due to its nature; nothing affects gender, age, education, etc.). The role of psychographics will be tested through mediation analysis as they are first affected by the independent variable (consumers' lifestyle can be affected by several factors including social media marketing) then is supposed to affect the dependent variable.

\section{METHODOLOGY}

\section{Population and Sample}

According to the Arab social media report (2015), smartphones are the main mode of access to social media. Most respondents (83\%) browse social media via their smartphones rather than lap or desktops. The majority (84\%) of social media users in Arab World visit Facebook through their smartphones and/ or tablets. To answer the research questions and achieve its objectives, smartphone users have been chosen as a population because smartphones users are not only brand page followers, rather, some of them are traditional marketing followers. Therefore, smartphone users are suitable as population for the purposes and hypotheses of the current study as they consist of consumers that prefer to know about brands through social media and consumers that prefer to know about brands through traditional media. This study will be limited to studying the effect of social media marketing as representative of social media marketing on brand loyalty.

Sample units are Egyptian smartphone users whether following a brand Facebook page or not. The researcher has tried to survey consumers above 18 years old who are using smartphone for at least

Figure 1. Research proposed model and hypothesized relationships ( ${ }^{*} G e n d e r$, age, and education)

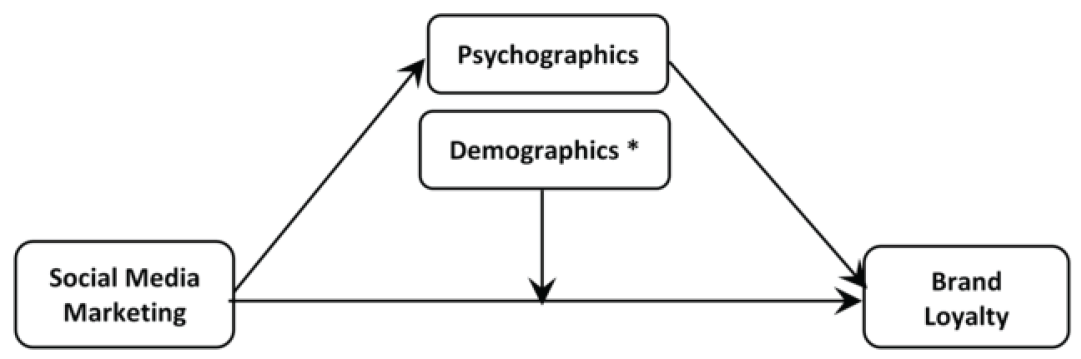


six months and for consumers who depend on Social media marketing, they should have been doing that for at least three months. The experimental group consisted of 251 respondents of smartphone users in Egypt and so does the control group.

\section{Measures}

Based on research objectives, research variables are Social media marketing as an independent variable, brand loyalty as dependent variable, demographics are moderating variables, and psychographics are mediating variables.

Brand loyalty has been operationally defined through the main two dimensions comprising the brand loyalty scale. Many authors have agreed on attitudinal and behavioral loyalty as the dimensions of brand loyalty. Although the scale of Zeithmal et al (1996) is the first and their work is pioneer, the researcher will use the scale of Suarez Alvarez, Díaz Martín \& Casielles (2007) scale with slight modification to measure brand loyalty. The rationale is that Zeithmal et al (1996) is too short or too brief, moreover, Suarez Alvarez, Díaz Martín, \& Casielles (2007) scale is the most comprehensive scale.

Social media marketing is the independent variable. The treatment (Social media marketing) will be measured to make sure that the sampling unit in the experimental group has really been exposed to the treatment. The current study will use the scale developed by Kim \& Ko (2012) to measure Social media marketing as it is the most comprehensive one and has been lately validated (Yadav \& Rahman, 2017). Psychographics consists of three dimensions; activities, interest, and opinions and Yu (2011) measured e-lifestyle through four dimensions reflecting e-activities, e-opinions, e-interests, and e-values. This scale will be used to measure smartphone users' psychographics. Finally, Demographic characteristics include gender, age, and education as they have a direct influence on consumers' lifestyle and behavior.

\section{Data Analysis}

\section{Measure Goodness of Fit}

The test of goodness of fit is established through validity and reliability of the measures (Sekaran \& Bougie, 2016). Validity of the measures was approved through pilot study conducted on a convenience sample which comprised of 50 smartphone users in Egypt from the chosen governorates. Confirmatory factor analysis was used to examine the research variables' dimensionality (As shown in table 1). The analysis was performed with AMOS 24 and IBM SPSS 24.

Following Hair et al (2010) to evaluate construct validity, convergent validity was assessed by calculating the standardized factor loadings which are ideal when greater than 0.3 (Guilford, 1961, Brown, 2014). Several indicators have been used to evaluate the goodness of fit (GFI) of the model. Reliability: Cronbach's coefficient alpha (Cronbach's alpha; Cronbach, 1946) has been calculated for each variable as a whole and for each sub dimension as shown in table (1). It is obvious that all construct items had standardized factor loadings above 0.3 , $T$ values were significant at 0.01 , Cronbach alphas recorded more than .07 for the scale items, and model fit indicators are satisfactory. In general, these results suggest that the theoretical model used was valid.

\section{SAMPLE DESCRIPTION STATISTICS:}

The sample constitutes of 502 respondents of smartphone users in Egypt divided into two groups; experimental group (smartphone users who follow their brands page on Facebook) and control group (smartphone users who don't follow their brand pages on Facebook) of 251 respondents each. Follows in table (2) is the experimental and control group demographic descriptive statistics and other descriptive data such as smartphone brand used and period of acquisition. 
Table 1. Instrument validity (standardized confirmatory factor-analysis) and reliability (cronbach' alpha)

\begin{tabular}{|c|c|c|c|c|c|}
\hline \multicolumn{2}{|l|}{ Variables } & $\begin{array}{c}\text { Cronbach's } \\
\text { Alpha }\end{array}$ & $\begin{array}{c}\text { Standardized } \\
\text { loadings }\end{array}$ & t-value & P value \\
\hline \multicolumn{6}{|l|}{ Brand loyalty } \\
\hline \multirow{3}{*}{$\begin{array}{l}\text { Attitudinal } \\
\text { loyalty }\end{array}$} & AL1 & \multirow[b]{4}{*}{.795} & $.715^{\mathrm{a}}$ & --- & \\
\hline & AL 2 & & .745 & 10.561 & .000 \\
\hline & AL 3 & & .811 & 11.289 & .000 \\
\hline \multicolumn{2}{|c|}{ Attitudinal loyalty } & & & & \\
\hline \multirow{4}{*}{$\begin{array}{l}\text { Behavioural } \\
\text { loyalty }\end{array}$} & BL4 & & $.812^{\mathrm{a}}$ & --- & \\
\hline & BL5 & & .779 & 13.113 & .000 \\
\hline & BL6 & & .763 & 12.792 & .000 \\
\hline & BL7 & & .737 & 12.258 & .000 \\
\hline \multicolumn{2}{|c|}{ Behavioural loyalty } & .854 & & & \\
\hline \multicolumn{6}{|c|}{ Model fit indicators: $\chi 2 / d f=2.574, \mathrm{NFI}=.926, \mathrm{TLI}=961, \mathrm{CFI}=976, \mathrm{RMSEA}=.079$} \\
\hline \multicolumn{6}{|c|}{ Psychographics (e-lifestyle) } \\
\hline \multirow[t]{8}{*}{ e-activities } & acl & & $.467^{\mathrm{a}}$ & --- & \\
\hline & ac 2 & & .364 & 4.028 & .000 \\
\hline & ac 3 & & .476 & 4.793 & .000 \\
\hline & ac 4 & & .418 & 4.421 & .000 \\
\hline & ac 5 & & .443 & 4.600 & .000 \\
\hline & ac 6 & & .471 & 4.782 & .000 \\
\hline & ac 7 & & .503 & 4.955 & .000 \\
\hline & ac 8 & & .474 & 6.124 & .000 \\
\hline \multicolumn{2}{|c|}{ e-activities } & .704 & & & \\
\hline \multirow[t]{7}{*}{ E-interests } & In1 & & $.747^{\mathrm{a}}$ & --- & \\
\hline & $\operatorname{In} 2$ & & .667 & 10.220 & .000 \\
\hline & $\operatorname{In} 3$ & & .717 & 11.041 & .000 \\
\hline & In 4 & & .736 & 11.336 & .000 \\
\hline & In5 & & .718 & 11.051 & .000 \\
\hline & In6 & & .714 & 10.987 & .000 \\
\hline & $\operatorname{In} 7$ & & .639 & 9.772 & .000 \\
\hline \multicolumn{2}{|c|}{ e-interests } & .873 & & & \\
\hline e- opinions & Op1 & & .984 & 28.936 & .000 \\
\hline & Op2 & & .458 & 7.879 & .000 \\
\hline & Op3 & & .571 & 10.470 & .000 \\
\hline & Op4 & & .329 & 6.829 & .000 \\
\hline & Op5 & & .491 & 8.231 & .000 \\
\hline & Op6 & & $.632^{\mathrm{a}}$ & --- & \\
\hline e-op & ion & .836 & & & \\
\hline E-values & V1 & & $.948^{\mathrm{a}}$ & --- & \\
\hline & $\mathrm{V} 2$ & & .397 & 7.129 & .000 \\
\hline & V3 & & .497 & 8.466 & .000 \\
\hline & V4 & & .643 & 6.118 & .000 \\
\hline & V5 & & .932 & 16.530 & .000 \\
\hline & V6 & & .932 & 7.193 & .000 \\
\hline & V7 & & .475 & 8.438 & .000 \\
\hline e-va & & .891 & & & \\
\hline Model fit indica & $\mathrm{s}: \chi^{2 / d f}=$ & $\mathrm{NFI}=831, \mathrm{~T}$ & $=.885, \mathrm{CFI}=.8$ & 9, RMSE & .071 \\
\hline Social Media M & keting & & & & \\
\hline Entertainment & E1 & & & & \\
\hline & E2 & & & & \\
\hline Ente & ainment & .765 & $.595^{\mathrm{a}}$ & --- & \\
\hline Interaction & I1 & & & & \\
\hline & I2 & & & & \\
\hline & \begin{tabular}{|l|}
$\mathrm{I} 3$ \\
\end{tabular} & & & & \\
\hline Int & etion & .784 & .722 & 8.111 & .000 \\
\hline Trendiness & T1 & & & & \\
\hline & $\mathrm{T} 2$ & & & & \\
\hline & T3 & & & & \\
\hline Tre & iness & .714 & .728 & 8.149 & .000 \\
\hline Customization & C1 & & & & \\
\hline & $\mathrm{C} 2$ & & & & \\
\hline $\mathrm{Cu}$ & mization & .764 & .738 & 8.203 & .000 \\
\hline Word of mouth & W1 & & & & \\
\hline & W2 & & & & \\
\hline Wor & f mouth & .731 & .676 & 9.286 & .000 \\
\hline $\begin{array}{l}\text { Confirmatory fac } \\
\text { scale consists to } \\
\text { dimensions level. }\end{array}$ & $\begin{array}{l}\text { analysis } \\
\text { dimensi }\end{array}$ & $\begin{array}{l}\text { theen appliec } \\
\text { th less than } 3\end{array}$ & $\begin{array}{l}\text { social med } \\
\text { tements, rath }\end{array}$ & $\begin{array}{l}\text { marketing } \\
\text { it has bee }\end{array}$ & $\begin{array}{l}\text { aps as the } \\
\text { applied on }\end{array}$ \\
\hline $\begin{array}{l}\text { Note: }{ }^{a} \text { Fixed para } \\
\text { P value is signific }\end{array}$ & $\begin{array}{l}\text { ters. } \\
\text { t at less } t\end{array}$ & & & & \\
\hline
\end{tabular}


Table 2. Descriptive statistics of sample respondents ( $\mathrm{N}=502)$

\begin{tabular}{|c|c|c|c|c|c|}
\hline \multirow{2}{*}{ Item } & \multirow{2}{*}{ Details } & \multicolumn{2}{|c|}{ Experimental group } & \multicolumn{2}{|c|}{ Control group } \\
\hline & & Frequency & $\%$ & Frequency & $\%$ \\
\hline \multirow{3}{*}{ Gender } & Male & 128 & 51 & 129 & 51.4 \\
\hline & Female & 123 & 49 & 122 & 48.6 \\
\hline & Total & 251 & 100 & 251 & 100 \\
\hline \multirow{6}{*}{ Age } & Less than 20 & 51 & 20.3 & 43 & 17.1 \\
\hline & From 20 to $<30$ & 50 & 19.9 & 62 & 24.7 \\
\hline & From 30 to $<40$ & 54 & 21.5 & 52 & 20.7 \\
\hline & From 40 to $<50$ & 46 & 18.3 & 48 & 19.1 \\
\hline & More than 50 & 50 & 19.9 & 46 & 18.3 \\
\hline & Total & 251 & 100.0 & 251 & 100.0 \\
\hline \multirow{4}{*}{ Education } & Moderate education & 91 & 36.3 & 40 & 15.9 \\
\hline & Bachelor's degree & 79 & 31.5 & 158 & 62.9 \\
\hline & $\begin{array}{l}\text { Post bachelor's } \\
\text { degree }\end{array}$ & 81 & 32.3 & 53 & 21.1 \\
\hline & Total & 251 & 100.0 & 251 & 100.0 \\
\hline
\end{tabular}

As shown in table (2), of the experimental group, $51 \%$ were male and $49 \%$ were females while $51.4 \%$ were males and $48.6 \%$ were females in the control group.

Moreover, most respondents of the experimental group (21.5\%) were between 30-40 years old most of the control group (24.7\%) were between 20-30 years old. Most respondents of the experimental group $(36.3 \%$ ) had moderate education while $62.9 \%$ of the control group had bachelor's degrees.

\section{DESCRIPTIVE STATISTICS}

Table (3) shows variables' descriptive statistics, respondents of the experimental group indicated high levels of mean score for Social media marketing (mean=3.5920, SD=.69784) and high mean score for brand loyalty (mean $=3.5959, \mathrm{SD}=.81002$ ) compared with the control group brand loyalty (mean $=3.3051, \mathrm{SD}=.67282$ ).

Next, a correlation matrix of all variables has been developed and used to test the hypothesis and the results are shown in table (4).

Correlation coefficients for Social media marketing and brand loyalty and psychographics recorded $.581 * *$ and $.674 * *$ respectively $(\mathrm{p}<.01)$.

\section{HYPOTHESIS TESTING RESULTS}

This research aimed at testing 8 hypotheses; following is the procedures undertaken to test these hypotheses, then results are discussed.

\section{The Effect of Social Media Marketing on Brand Loyalty}

The first hypothesis has been tested after executing two steps; (1) comparing the mean scores of brand loyalty for the two groups (experimental and control), and (2) regression analysis. The independent 
Table 3. Variables' descriptive statistics ( $n=251$ for each group)

\begin{tabular}{|c|c|c|c|c|c|c|}
\hline \multirow[b]{2}{*}{ Variables } & \multicolumn{3}{|c|}{ Experimental group } & \multicolumn{3}{|c|}{ Control group } \\
\hline & Mean & $\begin{array}{l}\text { Standard } \\
\text { Deviation }\end{array}$ & Variation & Mean & $\begin{array}{l}\text { Standard } \\
\text { Deviation }\end{array}$ & Variation \\
\hline Attitudinal loyalty & 3.6255 & .86440 & .747 & 3.2696 & .76152 & .580 \\
\hline Behavioral loyalty & 3.5737 & .87524 & .766 & 3.3317 & 69807 & .487 \\
\hline Brand loyalty & 3.5959 & .81002 & .656 & 3.3051 & .67282 & .453 \\
\hline E-Activities & 3.7141 & .67004 & .449 & --- & --- & --- \\
\hline E-Interests & 4.0262 & .67658 & .458 & --- & --- & --- \\
\hline E- Opinions & 4.2231 & 63493 & .403 & --- & --- & --- \\
\hline E-Values & 4.0085 & .64016 & .410 & --- & --- & --- \\
\hline Psychographics & 3.9748 & .51379 & .264 & --- & --- & --- \\
\hline Entertainment & 3.6275 & .88073 & .776 & --- & --- & --- \\
\hline Interaction & 3.7052 & .89235 & .796 & --- & --- & --- \\
\hline Trendiness & 3.5963 & .82619 & .683 & --- & --- & --- \\
\hline Customization & 3.6892 & .82767 & .685 & --- & --- & --- \\
\hline Word of Mouth & 3.2829 & 1.1196 & 1.254 & --- & --- & --- \\
\hline $\begin{array}{l}\text { Social media } \\
\text { marketing }\end{array}$ & 3.5920 & .69784 & .487 & --- & --- & --- \\
\hline
\end{tabular}

Table 4. Correlation Matrix of research variables

\begin{tabular}{|l|l|l|l|l|l|l|}
\hline \multicolumn{2}{|c|}{ Variables } & \multicolumn{1}{|c|}{ Mean } & \multicolumn{1}{|c|}{ SD } & \multicolumn{1}{|c|}{$\mathbf{2}$} & \multicolumn{1}{c|}{$\mathbf{3}$} & \multicolumn{1}{c|}{$\mathbf{5}$} \\
\hline 1 & Social media marketing & 3.5920 & .69784 & & & \\
\hline 2 & Brand loyalty & 3.5959 & .81002 & $.993 * *$ & 1 & \\
\hline 3 & Psychographics & 3.9748 & .51379 & $.751^{* *}$ & $.743^{* *}$ & 1 \\
\hline
\end{tabular}

${ }^{* *}$ Correlation is significant at the 0.01 level (2-tailed).

samples t-test compares the means of the experimental and control group in order to determine whether population means (brand loyalty) are significantly different. Table (5) shows the results of the independent-samples t-tests.

As shown in table (5), $\mathrm{p}$ value is lower than the required cut-off of .05 for the brand loyalty; $(\mathrm{t}=4.376)$, thus, it is indicated that there is a statistically significant difference in the mean of brand loyalty among smartphone users in Egypt scores between experimental group and control group. This difference is for the social media marketing group. Brand loyalty of the experimental group recorded 3.5959 while the control group's recorded 3.3051.

Table 5. Independent-samples t-test results

\begin{tabular}{|c|c|c|c|c|c|}
\hline \multirow{2}{*}{ Variables } & \multirow{2}{*}{$\mathbf{T}$} & \multirow{2}{*}{ df } & \multicolumn{2}{|c|}{ Means } & \multirow{2}{*}{ Sig p value } \\
\hline & & & Experiment & Control & \\
\hline Brand loyalty & 4.376 & 500 & 3.5959 & 3.3051 & 0.000 \\
\hline
\end{tabular}


Regression analysis has been conducted to ensure the previously shown results (independent samples t-test) that social media marketing significantly affects brand loyalty among smartphone users in Egypt. Results showed that social media marketing has a significant effect on brand loyalty among smartphone users in Egypt $\left(\beta=.581, \mathrm{C} . \mathrm{R} .=11.291, \mathrm{sig}=.00, \mathrm{R}^{2}=.338, \mathrm{~S} . \mathrm{E} .=.035\right)$. In other words, social media marketing explains $36 \%$ of the variances in brand loyalty among smartphone users in Egypt.

In sum, the current research results showed that Social media marketing significantly affects brand loyalty among smartphone users in Egypt as there is a significant difference between means of brand loyalty of experimental and control group as well as the significant regression coefficients for social media marketing and brand loyalty among smartphone users in Egypt. As there is still a debate about the effect of social media marketing on brand loyalty between the two sides (opponents and supporters), the role of some demographics and psychographics will be tested to clarify this debate.

\section{The Effect of Demographics}

To test the hypotheses 2-7, multi group analysis using SPSS Amos 24 has been employed. The samples were splitted into subsamples according to demographic features (e.g., males versus females, age groups., etc). A method known as the subgroup method is used for detecting moderating effects and has been extensively used in the literature (e.g., Brockman and Morgan, 2006; Hilal, 2021; Karikari, Osei-Frimpong, \& Owusu-Frimpong, 2017; Homburg and Giering, 2001; Khan \& Rahman, 2016).

\section{6/2/1/ The Effect of Gender}

Table (6) shows the effect of gender on the relationship between Social media marketing and brand loyalty among smartphone users in Egypt).

As shown in table (6), coefficients of determination between social media marketing and brand loyalty are more for males $\left(\mathrm{R}^{2}=.308\right)$ than females $\left(\mathrm{R}^{2}=.369\right)$. This implies that male respondents depend more on social media marketing than female respondents and social media marketing is more correlated with brand loyalty for male group than female respondents.

It is also shown in table (6) that the critical ratio for differences between males and females are lower than 1.96 (-.034) which means that social media marketing effect on brand loyalty for male respondents is the same as female respondents. It is concluded that, although correlation and regression coefficients varied between males and females, multi group analysis showed that gender does not affect the relationship between social media marketing and brand loyalty.

\section{6/2/2/ The Effect of Age}

Table (7) shows the effect of age on the relationship between Social media marketing and brand loyalty.

It is obvious that coefficients of determination and regression of social media marketing and brand loyalty varied greatly across age groups. Coefficients of determination and regression recorded the highest score of respondents who are more than 50 years old $\left(\mathrm{R}^{2}=.143, \beta=.379\right)$ followed by respondents less than 20 years old $\left(\mathrm{R}^{2}=.124, \beta=.352\right)$. Other age groups surprisingly recorder insignificant coefficients of determination and regression. However, the researcher cannot deduce a

Table 6. The effect of gender on the relationship between Social media marketing and brand loyalty

\begin{tabular}{|l|l|l|l|l|l|l|l|}
\hline & \multicolumn{1}{|c|}{ Gender } & \multicolumn{1}{|c|}{$\mathbf{R}^{2}$} & \multicolumn{1}{|c|}{ S.E. } & $\boldsymbol{\beta}$ & $\begin{array}{c}\text { Critical } \\
\text { Ratio }\end{array}$ & \multicolumn{1}{|c|}{ Sig } & $\begin{array}{c}\text { Critical ratio of } \\
\text { difference }^{\#}\end{array}$ \\
\hline \multirow{2}{*}{$\begin{array}{l}\text { SMM* on brand } \\
\text { loyalty }\end{array}$} & Female & .308 & .054 & .555 & 7.37 & .000 & \multirow{2}{*}{-.034} \\
\cline { 2 - 8 } & Male & .369 & .046 & .608 & 8.618 & .000 & \\
\hline
\end{tabular}

\#Absolute critical ratios less than 1.96 are insignificant.

Absolute critical ratios more than 1.96 are significant. 
Table 7. The effect of age on the relationship between social media marketing and brand loyalty

\begin{tabular}{|c|c|c|c|c|c|c|c|c|c|c|}
\hline & \multirow{2}{*}{$\mathbf{R}^{2}$} & \multirow{2}{*}{ S.E. } & \multirow{2}{*}{$\boldsymbol{\beta}$} & \multirow{2}{*}{$\begin{array}{c}\text { Critical } \\
\text { Ratio }\end{array}$} & \multirow{2}{*}{ sig } & \multicolumn{5}{|c|}{ Critical ratio of difference $^{\#}$} \\
\hline & & & & & & (1) & (2) & (3) & (4) & (5) \\
\hline (1) & .124 & .078 & .352 & 2.66 & .008 & --- & & & & \\
\hline (2) & .023 & .111 & .150 & 1.063 & .288 & -.670 & --- & & & \\
\hline (3) & .002 & .110 & -.046 & -.337 & .736 & -1.823 & -.993 & --- & & \\
\hline (4) & .013 & .092 & -.112 & -.759 & .448 & -2.307 & -1.302 & .227 & --- & \\
\hline (5) & .143 & .081 & .379 & 2.863 & .004 & .204 & .830 & 1.972 & 2.465 & --- \\
\hline \multicolumn{11}{|c|}{$\begin{array}{l}\text { (1) Less than } 20 \text { years old } \\
\text { (2) } 20-30 \text { years old } \\
\text { (3) } 30-40 \text { years old } \\
\text { (4) } 40-50 \text { years old } \\
\text { (5) More than } 50 \text { years old }\end{array}$} \\
\hline
\end{tabular}

"Absolute critical ratios less than 1.96 are insignificant.

Absolute critical ratios more than 1.96 are significant.

general trend of age concerning the effect of social media marketing and brand loyalty as coefficients of determination and regression are fluctuating.

As shown in table (7), some of the critical ratios for differences among age groups are significant and others aren't. Respondents who are less than 20 years old are significantly different from respondents who are more than 50 years old (critical ratio $=-2.307$ ), respondents who are between 30-40 years old are significantly different from respondents who are more than 50 years old (critical ratio $=1.972)$, respondents who are 40-50 years old are significantly different from respondents who are more than 50 years old (critical ratio $=2.465$ ), and respondents who are 30-40 years old are significantly different from respondents who are more than 50 years old (critical ratio $=-3.208$ ) which means that social media marketing effect on brand loyalty is significantly different across age groups.

Based on multi group analysis, it is concluded that age does affect the relationship between social media marketing and brand loyalty among smartphone users in Egypt.

\section{6/2/3/ The Effect of Education}

Table (8) shows the effect of education on the relationship between Social media marketing and brand loyalty among smartphone users in Egypt.

Table 8. The effect of education on the relationship between social media marketing and brand loyalty

\begin{tabular}{|c|c|c|c|c|c|c|c|c|}
\hline & \multirow[b]{2}{*}{$\mathbf{R}^{2}$} & \multirow[b]{2}{*}{ S.E. } & \multirow[b]{2}{*}{$\boldsymbol{\beta}$} & \multirow[b]{2}{*}{$\begin{array}{c}\text { critical } \\
\text { ratio }\end{array}$} & \multirow[b]{2}{*}{ sig } & \multicolumn{3}{|c|}{ Critical ratio of difference } \\
\hline & & & & & & Moderate & $\begin{array}{c}\text { University } \\
\text { degree }\end{array}$ & $\begin{array}{c}\text { Higher } \\
\text { than } \\
\text { university }\end{array}$ \\
\hline Moderate & .255 & .063 & .505 & 5.549 & .000 & 000 & & \\
\hline $\begin{array}{l}\text { University } \\
\text { degree }\end{array}$ & .001 & .085 & .032 & .285 & .776 & -3.081 & 000 & \\
\hline $\begin{array}{l}\text { Higher than } \\
\text { university }\end{array}$ & .071 & .064 & .267 & 2.475 & .013 & -2.157 & 1.254 & 000 \\
\hline
\end{tabular}

\# Absolute critical ratios less than 1.96 are insignificant.

Absolute critical ratios more than 1.96 are significant. 
As shown, coefficients of determination and regression of social media marketing and brand loyalty are partially significant and varied greatly across education groups. It is noted that coefficients of determination and regression of social media marketing and brand loyalty is the highest for respondents with moderate education $\left(\mathrm{R}^{2}=.255, \beta=.505\right)$, lowest for Higher than university groups $\left(\mathrm{R}^{2}=.071, \beta=.267\right)$, insignificant for the university degree holders.

As shown in table (8), some of the critical ratios for differences among education groups are significant while other are insignificant. Respondents with moderate education are significantly different from respondents with university degree (critical ratio=-3.081) and different from respondents with higher than university degree (critical ratio=-2.157). In other words, social media marketing effect on brand loyalty is significantly different across education groups.

Based on multi group analysis, it is concluded that education affects the relationship between social media marketing and brand loyalty among smartphone users in Egypt.

\section{The Role of Psychographics}

The role of psychographics has been explored through a test of path analysis for the direct and indirect relationships between social media marketing and brand loyalty among smartphone users in Egypt. Amos and IBM SPSS 22 have been used. After showing the analysis results, a discussion is presented.

Path analysis was employed to test the research hypothesis 3 which states that psychographics affect the relationship between Social media marketing and brand loyalty among smartphone users in Egypt. Figure (2) shows the results. The overall fit of the structural model to the data was highly acceptable $(\chi 2 / \mathrm{df}=--, \mathrm{CFI}=1$, NFI $=1$, TLI $=--$, RMSEA=-- $)$.

It is obvious from the previous figure that the indirect effect of social media marketing and brand loyalty through psychographics is stronger than the direct effect. As shown in figure (2), social media marketing direct effect recorded .15 while the indirect effect through psychographics recorded .64.

This indicates that psychographics enhanced the relationship between Social media marketing and brand loyalty among smartphone users in Egypt by more than 30\%. Table (9) shows the hypothesis testing and path analysis results.

It is obvious from table (9) that the indirect relationship between Social media marketing and brand loyalty is significant as regression weight estimate (CR) values for the path are more than 2.54. Moreover, the $\mathrm{p}$ value (.000) indicates that the regression weight for social media marketing in the prediction of brand loyalty is significantly different from zero at the 0.001 level (two-tailed).

Figure 2. The effect of consumers' psychographics in the relationship between social media marketing and brand loyalty among smartphone users in Egypt

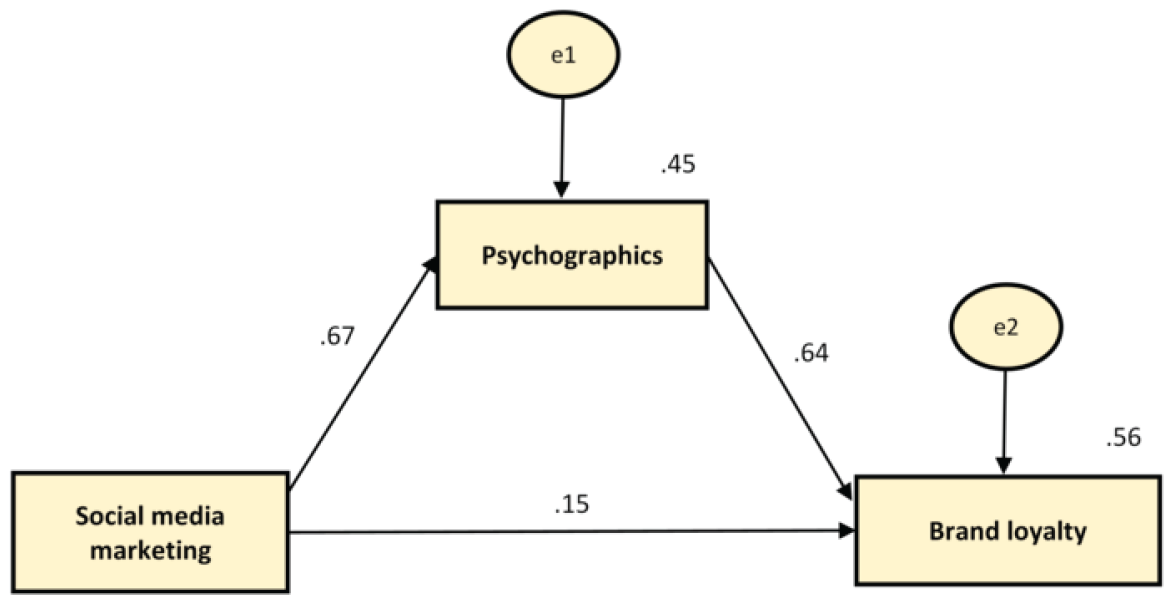


Table 9. Results of hypothesis testing and path analysis

\begin{tabular}{|l|l|l|l|l|l|}
\hline \multicolumn{1}{|c|}{ Paths } & \multicolumn{1}{c|}{ B } & \multicolumn{1}{c|}{ Estimate } & \multicolumn{1}{c|}{ S.E. } & \multicolumn{1}{c|}{ Critical Ratio } & P(sig) \\
\hline SMM* ---> Brand Loyalty & .148 & .100 & .038 & 2.610 & .009 \\
\hline SMM* ---> Psychographics & .674 & 1.158 & .080 & 14.423 & .000 \\
\hline Psychographics ---> Brand Loyalty & .643 & .254 & .022 & 11.375 & .000 \\
\hline
\end{tabular}

Therefore, psychographics significantly affect the relationship between social media marketing and brand loyalty among smartphone users in Egypt. Accordingly, hypothesis 5 is accepted.

Table (10) shows summary of hypotheses testing results.

\section{DISCUSSION AND CONCLUSION}

The current research results showed that Social media marketing significantly affects brand loyalty among smartphone users in Egypt as there is a significant difference between means of brand loyalty of experimental and control group as well as the significant regression coefficients for social media marketing and brand loyalty among smartphone users in Egypt. The current research results concerning the effect of social media marketing and brand loyalty are consistent with Gunelius (2011), and Chung \& Austria (2010), Azadi \& Rahimzadeh (2012), Swani et al (2013), and Erdoğmuş \& Cicek (2012). However, the current research opposed the results of Laroche, Habibi \& Richard (2013), Zheng et al

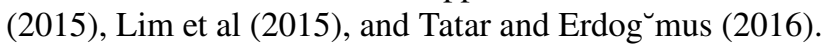

Several factors can interpret this result. First, one of the main online brand-related activities is entrainment (Vale \& Fernandes, 2018), smartphone users in Egypt found their brand platforms entertaining as the mean of entertainment recorded 3.6275. Smartphone brand owners made their interactions creative \& funny to attract browser's attention, increase traffic, and increase exposure which finally enhanced their loyalty with their smartphone brand. Second, interaction as a dimension of social media marketing has significantly influenced smartphone users' loyalty as its mean recorded 3.7052. Social media has created a totally new level of interaction between brands and consumers and consumers themselves. Conversations and talk between the two sides have enabled brand owners to build instant relationship and have the unique opportunity to communicate on a personal level with their customers which finally helped businesses to effectively interact their followers on social media. Moreover, interaction enhanced loyalty to the brand; consumers are now more ready to recommend this brand, make positive comments about it, and consider it as first choice when thinking of new purchase. Finally, it raised level of awareness of the brand, consumers knew more about the brand, its features, and recall it in different purchase decision making processes.

Table 10. Summary of hypotheses testing results

\begin{tabular}{|l|l|}
\hline \multicolumn{1}{|c|}{ Hypotheses } & \multicolumn{1}{c|}{ Decision } \\
\hline SMM $^{*}$---> Brand Loyalty & Accepted \\
\hline Demographics affect SMM ---> Brand Loyalty & Partially Accepted \\
\hline - Gender effect & Denied \\
\hline - Age effect & Supported \\
\hline - Education effect & Supported \\
\hline Psychographics affect SMM ${ }^{---->}$Brand Loyalty & Accepted \\
\hline
\end{tabular}


Third, in an ever changing and updated world, trendiness (mean=3.5963) has forced itself and played a significant role nowadays where smartphone users found their brand pages continuously updated and respond to their feedback in a timely manner which finally enhanced brand loyalty. Often, customers are taking on social media about complaints where $78.5 \%$ people expressed their sentiments or views (e.g. satisfaction, happiness, disapproval, anger, etc.) when using social media (Arab Social Media Report, 2017), therefore, mobile brands had a plan to respond to complaints in the right way and on the right time. Forth, information seeking is one of the main activities of Facebook users when browsing their brand pages. Customization mean recorded 3.6892 which means that social media marketing of smartphone brands provided consumers with information and instructional manuals. It enabled smartphone brands to provide more useful interesting applications to draw their customers' attentions and provide customized services.

Fifth, smartphone brands social media marketing has created a whole new level of word of mouth. Social media had been best used to reach consumers directly; certainly, those consumers can also reach other consumers, which create electronic word of mouth on which consumers rely because peer recommendations are credible and trustworthy, which has been finally enhanced smartphone brands loyalty.

Results showed that psychographics significantly affect the relationship between Social media marketing and brand loyalty among smartphone users in Egypt. Several factors can interpret this result. Psychographics pertain to people's lifestyle (activities, interests, opinions and values). Lifestyle is viewed as a summary concept that offers the possibility of new insights, unusual conclusions, and provides "a broader, more three-dimensional view of the consumers" (Hawes, 1978). These are a key to understanding motivations and why people do what they do.

Smartphone brands owners were able to understand these kinds of psychographic differences and as a result, social media marketing tools made psychographic insights actionable in a way that was nearly impossible before. Using psychographics allowed marketers to do smarter keyword targeting for example, targeting one message about the new smartphone with specific features to browsers who recently searched for smartphones with this feature and another message to consumers complaints from smartphones without this feature.

Social media marketing enabled smartphone brands owners to explore browsers' activities, interests, opinions, and values, design marketing messages suitable for each lifestyle category, target these messages for each category easily and effectively. Moreover, social media marketing made psychographic differences much more clear, easy to access, and relevant to both consumers and marketers. Social media made psychographics more actionable and made psychographic differences more important. Moreover, it enabled marketers to access psychographic insights more easily. Furthermore, social media presence enabled marketers to influence consumers' lifestyle $(\beta=1.16$, $\mathrm{P}<.01$ ). As mentioned before, marketers can now easily explore fans' lifestyles and tailor marketing efforts to better suit specific categories and even more it enabled marketers to make shifts in consumers' activities and cut consumers' time to newly new activities that had never been done before; share opinions within network communities, chat with friends or colleagues/classmates, participate in social events, or read news or get data.

Moreover, social media marketing has made a shift in consumers' interests from tangible world to virtual settings; consumers would like now to stay updated with the latest electronic development, like gaining knowledge through online, like to participate in the network of social communities, and enjoy online shopping. Furthermore, social media marketing has reversed consumers' opinions from resisting the new mobile technology to believe now that continued development of internet services on mobile is positive for society, culture, economy, and brings happiness to daily life. Finally, social media marketing has transferred consumers' values to the favor of internet applications and made them believe that using the internet on the phone enhances the convenience in consumers' life, enhances interaction among people, and provides more new knowledge. 
All the previous shits in consumers' psychographics accompanied with Social media marketing have all enhanced consumers brand loyalty among smartphone users in Egypt. It is now concluded that psychographics affects the relationship between Social media marketing and brand loyalty. In sum, research hypotheses have been all tested and results have been discussed. It is concluded that most of the research hypotheses are supported and the research gap concerning the ambiguity of the relationship between Social media marketing and brand loyalty has been almost clarified by the supported role of demographics and psychographics.

\section{PRACTICAL IMPLICATION}

The main purpose is to help managers to understand the benefits of social media (Facebook) and how they can have an impactful social marketing method and strategy. Therefore, the following practical implications have been made clear. The current study's results concerning the increasing utilization of social media marketing offers valuable insights and implications. Social media marketing has the same advantages and benefits as offline or the traditional media and more. The vast reach, interactive interface, recommendations and electronic word of mouth, low cost, and popularity of Facebook are all factors prompting brand managers to take advantage of such characteristics. The findings in this study underpin the relevance of social media for brand management. This study highlighted Facebook as an important and integral part of the marketing communication strategy to minimize managers' doubts about the usefulness of social media involvements. Taking into consideration the creation and management of interaction between brand owners and customers and customers each other can significantly enhance consumers brand loyalty.

Social media marketing through the creation of positive word of mouth and the management of negative word of mouth will significantly enhance consumers brand loyalty. When the contents shown in smartphone brand on Facebook page is the newest information and when the page is characterized by quick response to comments and complaints (trendiness), brand owners will definitely achieve greater loyalty of smartphone users in Egypt. Surprisingly, if the brand page is providing entertaining content and customized services, enhancing brand loyalty among smartphone users in Egypt is not assured. It is not enough for marketing managers to simply measure and enhance brand loyalty among smartphone users in Egypt through social media marketing in isolation from demographics.

Targeting Social media marketing messages with the final aim of enhancing brand loyalty among smartphone users in Egypt to specific groups based on their age and education makes marketers work more efficiently. It is not sufficient for marketing managers to simply measure and enhance brand loyalty through social media marketing in isolation from psychographics. Targeting social media marketing messages with the final aim of enhancing brand loyalty to specific smartphone users' groups based on their activities, interests, opinions, and values makes marketers work more efficient.

Unlike traditional marketing, social media marketing is relatively low in investment costs and enables smartphone brands owners to engage in interactive relationships with current and potential customers. Finally, social media activities are used as means of gathering information and learning about consumers and their attitudes in an economic way.

\section{LIMITATIONS AND FUTURE RESEARCH}

In spite of the importance of the current research results, there are some limitations. Based on these limitations, several future research areas are suggested. First, the current research had focused on brand loyalty as a consequence of social media marketing in smartphones industries context, however, other contexts should be examined such as food industries, home appliances and electronics, cars and motors. Second, the current research had focused on consequences of social media marketing such as brand loyalty, however, other consumer-brand relationships that have never been studied in Egyptian 
context should be examined such as brand involvement, attachment, defense, love, identification, engagement, awareness, and image.

Third, the current research had focused on consequences of social media marketing (brand loyalty), however, another customers-related marketing concepts such as trust, delight, purchase intention, and commitment should be studied. Forth, this study had focused on Social media marketing consequences from customers' viewpoints, however, Social media marketing financial consequences such as return on investment, return on equity, and earnings are suggested for future research. Fifth, this study has been limited on Facebook as one of the most famous social media, however other social media platforms differ in browsing and sharing styles, studying the effect of social media marketing executed on twitter, youtube, and Instagram is suggested. Sixth, this study has been executed through ex-post facto design which is a quasi-experiment design which may affect the causality of the relationships among the research variables, therefore, other true experiment designs are recommended to be used for better cause-effect relationships. 


\section{REFERENCES}

Aaker, D. A. (2012). Building strong brands. Simon and Schuster.

Abdelsalam, S., Salim, N., Alias, R. A., \& Husain, O. (2020). Understanding Online Impulse Buying Behavior in Social Commerce: A Systematic Literature Review. Academic Press.

Abeza, G. Z. (2012) An exploratory study of the opportunities and challenges of social media in meeting relationship marketing goals in sport organizations (Doctoral dissertation). University of New Brunswick, Faculty of Kinesiology.

Alalwan, A. A. (2018). Investigating the impact of social media advertising features on customer purchase intention. International Journal of Information Management, 42, 65-77. doi:10.1016/j.ijinfomgt.2018.06.001

Alhaddad, A. (2015). A structural model of the relationships between brand image, brand trust and brand loyalty. International Journal of Management Research and Reviews, 5(3), 137.

Alkhas, A. 2011. An examination of Internet social media marketing in higher education institutions (Doctoral dissertation).

Aloch. (2017). Social media marketing and business growth of commercial (Doctoral dissertation). School of Business, University of Nairobi.

Amin, H., Qureshi, J. A., \& Chandio, S. (2017). Cultural, Ethical and Legal Considerations of Using Social Media Marketing in Karachi-Pakistan. Journal of Independent Studies \& Research: Management \& Social Sciences \& Economics, 15(2), 165-179. doi:10.31384/jisrmsse/2017.15.2.11

Arab social media report. (2015). Arab Social Media Influencers Summit. https://www.arabsocialmediareport. com/home/index.aspx

Arab social media report. (2017). Arab Social Media Influencers Summit. https://www.arabsocialmediareport. com/home/index.aspx

Azadi, S., \& Rahimzadeh, E. (2012). Developing marketing strategy for electronic businesses by using McCarthy's four marketing model mix and Porter's five competitive forces. EMAJ: Emerging Markets Journal, 2(2), 47-58. doi:10.5195/EMAJ.2012.25

Bieda, J. C., \& Kassarjian, H. H. (1971). An overview of market segmentation. In Marketing in a Changing Worlds. AMA.

Bonds-Raacke, J., \& Raacke, J. (2010). MySpace and Facebook: Identifying dimensions of uses and gratifications for friend networking sites. Individual Differences Research, 8(1).

Botha, H. (2014). Considerations and implications of social media and the integration thereof in the sales and marketing process: A Pharmaceutical perspective (Doctoral dissertation). University of Pretoria.

Brockman, B. K., \& Morgan, R. M. (2006). The Moderating Effect of Organizational Cohesiveness in Knowledge Use and New Product Development. Journal of the Academy of Marketing Science, 34(3), $295-307$. doi:10.1177/0092070306286707

Bruhn, M., Schoenmueller, V., \& Schäfer, D. B. (2012). Are social media replacing traditional media in terms of brand equity creation? Management Research Review, 35(9), 770-790. doi:10.1108/01409171211255948

Brunsø, K., Verbeke, W., Olsen, S. O., \& Jeppesen, L. F. (2009). Motives, barriers, and quality evaluation in fish consumption situations. British Food Journal, 111(7), 699-716. doi:10.1108/00070700910972387

Calder, B. J., Malthouse, E. C., \& Schaedel, U. (2009). An experimental study of the relationship between online engagement and advertising effectiveness. Journal of Interactive Marketing, 23(4), 321-331. doi:10.1016/j. intmar.2009.07.002

Chanthinok, K., Ussahawanitichakit, P., \& Jhundra-indra, P. (2015, July). Social media marketing strategy and marketing outcomes: A conceptual framework. Allied Academies International Conference. Academy of Marketing Studies Proceedings, 20(2), 35. 
Chen, S. C., \& Lin, C. P. (2019). Understanding the effect of social media marketing activities: The mediation of social identification, perceived value, and satisfaction. Technological Forecasting and Social Change, 140, 22-32. doi:10.1016/j.techfore.2018.11.025

Chung, C., \& Austria, K. (2010). Social media gratification and attitude toward social media marketing messages: A study of the effect of social media marketing messages on online shopping value. Proceedings of The Northeast Business \& Economics Association, 581-586.

Costa, T., Borges-Tiago, T., \& Tiago, F. (2018). Pharmaceutical Communication over Social Media Channels: 24/7 Management Challenges. In Digital Communication Management. IntechOpen. doi:10.5772/intechopen.75990

Cronbach, L. J. (1946). A case study of the split half reliability coefficient. Journal of Educational Psychology, 37(8), 473-480. doi:10.1037/h0054328 PMID:20283206

Dayan, M., Ozer, M., \& Almazrouei, H. (2017). The role of functional and demographic diversity on new product creativity and the moderating impact of project uncertainty. Industrial Marketing Management, 61, 144-154. doi:10.1016/j.indmarman.2016.04.016

El Assi, S. A. S. (2019). Research Methodology: Designs and Methods. Academic Press.

Engel, J., Blackwell, R., \& Miniard, P. (1990). Consumer Behavior (6th ed.). The Dryden Press.

Engel, J. F., Miniard, P. W., \& Blackwell, R. D. (2006). Consumer behavior (10th ed.). Thomson South-Western. Mason.

Erdoğmuş, İ. E., \& Cicek, M. (2012). The impact of social media marketing on brand loyalty. Procedia: Social and Behavioral Sciences, 58, 1353-1360. doi:10.1016/j.sbspro.2012.09.1119

Evans, D. (2010). Social media marketing: the next generation of business engagement. John Wiley \& Sons.

Fisher, T. (2009). ROI in social media: A look at the arguments. Journal of Database Marketing \& Customer Strategy Management, 16(3), 189-195. doi:10.1057/dbm.2009.16

Galal, T. F. (2017). The relationship between marketing communications via social networking sites and the spreading of investment culture of the Egyptian stock exchange: An applied on the customers of brokerage firms in Dakahlia Governorate (Master Dissertation). Mansoura University.

Garnyte, M., \& de Ávila Pérez, A. (2009). Exploring Social Media Marketing. Aarhus School of Business, University of Aarhus.

Gazzar, N. E. (2013). The role of social media in the formation of public opinion towards Islamists: A content analysis. Journal of Arab \& Muslim Media Research, 6(1), 35-49. doi:10.1386/jammr.6.1.35_1

Girard, T., Korgaonkar, P., \& Silverblatt, R. (2003). Relationship of type of product, shopping orientations, and demographics with preference for shopping on the Internet. Journal of Business and Psychology, 18(1), 101-120. doi:10.1023/A:1025087021768

Gironda, J. (2014). Tailored vs. invasive advertising: An empirical examination of antecedents and outcomes of consumers' attitudes toward personalized advertising. Florida Atlantic University.

Golijan, R., (2011). Just how many active Twitter users are there. Academic Press.

Gordon, A. (2017). Social Media Marketing Strategies in Nonprofit Professional Membership Organizations. Academic Press.

Guilford, J. P. (1961). Creative Thinking in Children at The Junior High School Levels. Academic Press.

Gunelius, S. (2011). 30 - Minute Social Media Marketing. McGraw Hill.

Hair, J. F., Black, W. C., Babin, B. J., \& Anderson, R. E. (2010). Multivariate data analysis (7th ed.). Upper Saddle River, NJ: Prentice Hall.

Hajli, N., \& Laroche, M. (2019). Applications of business intelligence and analytics in social media marketing. Academic Press. 
Hassan, S. H., Ramayah, T., Mohamed, O., \& Maghsoudi, A. (2015). E-lifestyle, customer satisfaction, and loyalty among the generation Y mobile users. Asian Social Science, 11(4), 157. doi:10.5539/ass.v11n4p157

Hawes, D. K. (1978). Empirically profiling four recreational vehicle market segments. Journal of Travel Research, 16(4), 13-20. doi:10.1177/004728757801600403

Hilal, O. A. (2021). The moderating role of self-efficacy in the relationship between workplace envy and social undermining. Global Business and Organizational Excellence, 40(6), 28-40.

Hoffman, D. L., \& Fodor, M. (2010). Can you measure the ROI of your social media marketing? MIT Sloan Management Review, 52(1), 41.

Homburg, C., \& Giering, A. (2001). Personal characteristics as moderators of the relationship between customer satisfaction and loyalty-An empirical analysis. Psychology and Marketing, 18(1), 43-66. doi:10.1002/15206793(200101)18:1<43::AID-MAR3>3.0.CO;2-I

Hoy, M. G., \& Milne, G. (2010). Gender differences in privacy-related measures for young adult Facebook users. Journal of Interactive Advertising, 10(2), 28-45. doi:10.1080/15252019.2010.10722168

Hustad, T. P., \& Pessemier, E. A. (1971). Segmenting consumer markets with activity and attitude measures. Institute for Research in the Behavioral, Economic, and Management Sciences, Herman C. Krannert Graduate School of Industrial Administration, Purdue University.

Hutter, K., Hautz, J., Dennhardt, S., \& Füller, J. (2013). The impact of user interactions in social media on brand awareness and purchase intention: The case of MINI on Facebook. Journal of Product and Brand Management, 22(5/6), 342-351. doi:10.1108/JPBM-05-2013-0299

Ioakimidis, M. (2010). Online marketing of professional sports clubs: Engaging fans on a new playing field. International Journal of Sports Marketing \& Sponsorship, 11(4), 2-13. doi:10.1108/IJSMS-11-04-2010-B002

Karikari, S., Osei-Frimpong, K., \& Owusu-Frimpong, N. (2017). Evaluating individual level antecedents and consequences of social media use in Ghana. Technological Forecasting and Social Change, 123, 68-79. doi:10.1016/j.techfore.2017.06.023

Karimi, S., \& Naghibi, H. S. (2015). Social media marketing (SMM) strategies for small to medium enterprises (SMEs). International Journal of Information, Business and Management, 7(4), 86.

Khan, I., \& Rahman, Z. (2016). E-tail brand experience's influence on e-brand trust and e-brand loyalty: The moderating role of gender. International Journal of Retail \& Distribution Management, 44(6), 588-606. doi:10.1108/IJRDM-09-2015-0143

Kim, A. J., \& Ko, E. (2012). Do social media marketing activities enhance customer equity? An empirical study of luxury fashion brand. Journal of Business Research, 65(10), 1480-1486. doi:10.1016/j.jbusres.2011.10.014

Koufaris, M. (2002). Applying the technology acceptance model and flow theory to online consumer behavior. Information Systems Research, 13(2), 205-223. doi:10.1287/isre.13.2.205.83

Laroche, M., Habibi, M. R., \& Richard, M. O. (2013). To be or not to be in social media: How brand loyalty is affected by social media? International Journal of Information Management, 33(1), 76-82. doi:10.1016/j. ijinfomgt.2012.07.003

Lee, C., Kim, J., \& Chan-Olmsted, S. M. (2011). Branded product information search on the Web: The role of brand trust and credibility of online information sources. Journal of Marketing Communications, 17(5), 355-374. doi:10.1080/13527266.2010.484128

Leung, X. Y. (2012). The marketing effectiveness of hotel Facebook pages: From perspectives of customers and messages. Academic Press.

Lim, J. S., Hwang, Y., Kim, S., \& Biocca, F. A. (2015). How social media engagement leads to sports channel loyalty: Mediating roles of social presence and channel commitment. Computers in Human Behavior, 46, 158-167. doi:10.1016/j.chb.2015.01.013

Liu, D. (2012). Benchmarking Data Reveals Pharmaceutical Industry Not Connecting Social Media Data with Marketing Strategies. IBM Global Business Services, 6. 
Lorenzo-Romero, C., Constantinides, E., \& Alarcón-del-Amo, M. (2013). Social Media as Marketing Strategy: An Explorative Study on Adoption and Use by Retailers \# \#This study is framed within Research Project with reference number ECO2009-08708 (Ministerio de Ciencia e Innovación, Gobierno de España, 2009-2013). Social Media in Strategic Management, 197-215.

Marshall, G. W., Moncrief, W. C., Rudd, J. M., \& Lee, N. (2012). Revolution in sales: The impact of social media and related technology on the selling environment. Journal of Personal Selling \& Sales Management, 32(3), 349-363. doi:10.2753/PSS0885-3134320305

Marzouk, W. G. (2016). Usage and Effectiveness of Social Media Marketing in Egypt: An Organization Perspective. Jordan Journal of Business Administration, 12(1), 209-238. doi:10.12816/0030062

Michaelidou, N., Siamagka, N. T., \& Christodoulides, G. (2011). Usage, barriers and measurement of social media marketing: An exploratory investigation of small and medium B2B brands. Industrial Marketing Management, 40(7), 1153-1159. doi:10.1016/j.indmarman.2011.09.009

Muntinga, D. G., Moorman, M., \& Smit, E. G. (2011). Introducing COBRAs: Exploring motivations for brandrelated social media use. International Journal of Advertising, 30(1), 13-46. doi:10.2501/IJA-30-1-013-046

Naylor, R. W., Lamberton, C. P., \& West, P. M. (2012). Beyond the "like" button: The impact of mere virtual presence on brand evaluations and purchase intentions in social media settings. Journal of Marketing, 76(6), 105-120. doi:10.1509/jm.11.0105

Oliver, R. L. (1999). Whence consumer loyalty? The Journal of Marketing, 33-44.

Ouoba, S. E. M. (2011). Investigating the Effectiveness of Social Media Sites in Shaping the Opinion of the Audience of Companies in the Food and Beverage Industry: Facebook and Twitter (Doctoral dissertation). Hawaii Pacific University.

Pieniak, Z., Verbeke, W., Scholderer, J., Brunsø, K., \& Ottar Olsen, S. (2008). Impact of consumers' health beliefs, health involvement and risk perception on fish consumption: A study in five European countries. British Food Journal, 110(9), 898-915. doi:10.1108/00070700810900602

Report, A. D. (2018). We are social. https://digitalreport.wearesocial.com/

Ross, C., Orr, E. S., Sisic, M., Arseneault, J. M., Simmering, M. G., \& Orr, R. R. (2009). Personality and motivations associated with Facebook use. Computers in Human Behavior, 25(2), 578-586. doi:10.1016/j. chb.2008.12.024

Schultz, D., Block, M., \& Viswanathan, V. (2014). Brand preference being challenged. Journal of Brand Management, 21(5), 408-428. doi:10.1057/bm.2014.5

Scott, D. (2007). The new rules of marketing and PR. John Wiley \& Sons.

Sekaran, U., \& Bougie, R. (2016). Research methods for business: A skill building approach. Academic Press.

Shareef, M. A., Mukerji, B., Dwivedi, Y. K., Rana, N. P., \& Islam, R. (2019). Social media marketing: Comparative effect of advertisement sources. Journal of Retailing and Consumer Services, 46, 58-69. doi:10.1016/j. jretconser.2017.11.001

Somali, H. (2018). Assimilation of social media marketing in Saudi large companies: Antecedents and consequences (Doctoral dissertation). Sheffield Hallam University.

Stephen, A. T. (2016). The role of digital and social media marketing in consumer behavior. Current Opinion in Psychology, 10, 17-21. doi:10.1016/j.copsyc.2015.10.016

Suarez Alvarez, L., Díaz Martín, A. M., \& Casielles, R. V. (2007). Relationship marketing and information and communication technologies: Analysis of retail travel agencies. Journal of Travel Research, 45(4), 453-463. doi: $10.1177 / 0047287507299593$

Swani, K., Milne, G. R., Cromer, C., \& Brown, B. P. (2013). Fortune 500 companies' use of twitter communications: A comparison between product and service tweets. International Journal of Integrated Marketing Communications, 5(2), 47-56. 
Tatar, Ş. B., \& Eren-Erdoğmuş, İ. (2016). The effect of social media marketing on brand trust and brand loyalty for hotels. Information Technology \& Tourism, 16(3), 249-263. doi:10.1007/s40558-015-0048-6

Tsitsi Chikandiwa, S., Contogiannis, E., \& Jembere, E. (2013). The adoption of social media marketing in South African banks. European Business Review, 25(4), 365-381. doi:10.1108/EBR-02-2013-0013

Vale, L., \& Fernandes, T. (2018). Social media and sports: Driving fan engagement with football clubs on Facebook. Journal of Strategic Marketing, 26(1), 37-55. doi:10.1080/0965254X.2017.1359655

Wang, X., Yu, C., \& Wei, Y. (2012). Social media peer communication and impacts on purchase intentions: A consumer socialization framework. Journal of Interactive Marketing, 26(4), 198-208. doi:10.1016/j. intmar.2011.11.004

Williams, J., \& Chinn, S. J. (2010). Meeting relationship-marketing goals through social media: A conceptual model for sport marketers. International Journal of Sport Communication, 3(4), 422-437. doi:10.1123/ijsc.3.4.422

Yadav, M., \& Rahman, Z. (2017). Measuring consumer perception of social media marketing activities in e-commerce industry: Scale development \& validation. Telematics and Informatics, 34(7), 1294-1307. doi:10.1016/j.tele.2017.06.001

Yu, C. S. (2011). Construction and validation of an e-lifestyle instrument. Internet Research, 21(3), 214-235. doi:10.1108/10662241111139282

Zeithmal, V. A., Berry, L. L., \& Parasuraman, A. (1996). The behavioral consequences of service quality. The Journal of Marketing, 31-46.

Zheng, X., Cheung, C. M., Lee, M. K., \& Liang, L. (2015). Building brand loyalty through user engagement in online brand communities in social networking sites. Information Technology \& People, 28(1), 90-106. doi:10.1108/ITP-08-2013-0144 